\title{
Exploring seagrass fish assemblages in relation to the habitat patch mosaic in the brackish Baltic Sea
}

\author{
Thomas A.B. Staveley ${ }^{1,2}$ (D) Patrick Hernvall ${ }^{1,2} \cdot$ Nellie Stjärnkvist $^{1} \cdot$ Felix van der Meijs $^{1,2} \cdot$ Sofia A. Wikström ${ }^{3}$. \\ Martin Gullström ${ }^{1,4}$
}

Received: 8 February 2019 / Revised: 19 June 2019 / Accepted: 19 December 2019 / Published online: 6 January 2020

(C) The Author(s) 2020

\begin{abstract}
Assessing the influence of habitat patch dynamics on faunal communities is a growing area of interest within marine ecological studies. This study sets out to determine fish assemblage composition in Zostera marina (L.) meadows and ascertain how habitat structural complexity and seascape structure (i.e. composition and configuration of habitat patches) influenced these assemblages in the northern Baltic Sea. Using ten seascapes (600 $\mathrm{m}$ in diameter), the fish assemblage was surveyed both in summer and autumn using beach seine. We found that the fish assemblage was clearly dominated by sticklebacks, followed by pipefish and with a general absence of larger piscivorous species. Biomass of fish did not differ between seasons, and low-level carnivores dominated the trophic structure. Overall, at the larger seascape-scale in summer, the proportion of bare soft sediment showed a negative relationship with fish biomass, while diversity of patches was found to exhibit a positive association with fish biomass. At the smaller habitat scale, both seagrass shoot height and density had a negative influence on fish biomass in both seasons. This study outlines new knowledge regarding how the mosaic of habitat patches shape seagrass fish assemblages in the northern Baltic Sea.
\end{abstract}

Keywords Seascape ecology $\cdot$ Zostera marina $\cdot$ Three-spined stickleback $\cdot$ Trophic level $\cdot$ Spatial pattern metrics

\section{Introduction}

Exploring spatial heterogeneity in the marine landscape, and the influence on faunal communities, is of particular significance within seascape ecology, which can offer knowledge at multiple scales regarding species-ecosystem dynamics (Pittman et al. 2011). Variations in the spatial patterning of

Communicated by S. E. Lluch-Cota

Electronic supplementary material The online version of this article (https://doi.org/10.1007/s12526-019-01025-y) contains supplementary material, which is available to authorized users.

Thomas A.B. Staveley

tom.staveley@su.se

1 Department of Ecology, Environment and Plant Sciences, Stockholm University, Stockholm, Sweden

2 AquaBiota Water Research, Stockholm, Sweden

3 Baltic Sea Centre, Stockholm University, Stockholm, Sweden

4 Department of Biological and Environmental Sciences, University of Gothenburg, Kristineberg, Fiskebäckskil, Sweden underwater habitats, thus altering physical and ecological processes, can contribute to changes in marine communities (Costa et al. 2018). Mobile organisms like fish are particularly sensitive, as many species need multiple habitats or patches over a varying spatial range throughout their life stages (Gillanders et al. 2003). Importantly, investigating complex trophic structure and interactions at a broader seascape scale in relation to ecological processes has been rarely studied (see e.g. Valentine et al. 2007; Heck et al. 2008) but is highly important to understand cross-habitat exchange and speciesenvironment relationships.

Seagrass is often studied in a seascape ecology context since it dominates many coastal areas (Boström et al. 2006); however, they are also sensitive to human-induced disturbances and have declined in many areas worldwide (Waycott et al. 2009). Seagrass habitats form meadows which provide many ecological functions, such as foraging grounds, shelter and nursery grounds for fish (Jackson et al. 2001; Heck 2003). At varying spatial and temporal scales, studies have investigated impacts from fine-scale habitat structural effects up to large-scale geographical influences on seagrass fish communities (e.g. Jackson et al. 2006; Gullström et al. 2008; Staveley et al. 2017; Scapin et al. 2018). 
In the brackish Baltic Sea, the dominating seagrass species Zostera marina is found in patchy meadows confined to wave-exposed shores. It generally grows at 2-6-m depth and rarely more shallow as they are displaced by competition with freshwater angiosperms and charophytes (e.g. Baden and Boström 2001; Boström et al. 2014). The role of brackish seagrass as habitat for fish is relatively little studied, especially with regard to a landscape ecology approach; therefore, it is of relevance to explore patterns of these important environments in relation to the fish community, particularly as this habitat is priority for conservation.

This study aims to address how the seascape structure, in terms of composition and configuration of habitat patches, influences fish assemblages in seagrass meadows of the Baltic Sea. Specifically, we set out to (i) quantify distribution patterns of fish in seagrass meadows in the Baltic Sea in summer and autumn, (ii) assess how the effects of habitat and seascape structure vary with trophic level status, and (iii) determine the influence of a mosaic of patches on the seagrass fish assemblage at a seasonal scale.

\section{Material and methods}

This study was conducted in ten seascapes $(600 \mathrm{~m}$ in diameter) in the Södermanland archipelago situated in the northern Baltic Sea proper (Fig. 1). All investigated sites had a central Z. marina meadow, but differed in composition and configuration of the surrounding seascape. As we were working in a complex archipelago environment, a $600-\mathrm{m}$ seascape was chosen as to ensure the inclusion of shallow water habitats and the assumption of capturing most fish species' home range (Pittman et al. 2004; Staveley et al. 2017). The study area is representative for the northern Baltic proper, with an archipelago of islands and skerries and seagrass meadows occurring mainly in wave-exposed sites with sandy substrate. The salinity in the area is around 6, which is at the salinity tolerance limit of seagrass plants (Boström et al. 2014).

In each seascape, seagrass shoot density and height in the central seagrass meadow were estimated to determine habitat structure (Fig. 1; Online Resource 1) during the summer (JuneJuly), while at the same time, assessment of the broader-scale seascape structure was performed using drop video surveying, GIS and spatial pattern metrics (see Staveley et al. 2017 for detailed methodology). To assess the composition of the seascape, proportion of habitats (i.e. Z. marina, bare soft sediment), mean patch size of all patches found in each seascape and Shannon's diversity index (measure of patch/habitat diversity) were used as predictor variables. The total edge of patches within each seascape was used as a predictor of seascape configuration (Fig. 1). In addition to the above habitats, the following were also categorized: soft sediment with mixed vegetation, rock, rock with mixed vegetation and blue mussel bank.
However, due to ensuring enough variation in habitat patches throughout the seascapes (as well as limiting the number of predictor variables), only the proportion of $Z$. marina and bare soft sediment were chosen for analyses.

To determine the fish assemblage in each focal seagrass meadow, beach seine fishing was conducted at one occasion in summer (June-July; time of day: 09:00-17:00) and one occasion in autumn (October; time of day: 09:00-15:00) 2017. All fish were identified (species identification keys see Kullander et al. 2012), counted, measured to the nearest $\mathrm{mm}$, and released back into the sea. If more than 50 individuals of a species were caught, we only measured 50 randomly sampled individuals, which we expect gives a reasonable representation of the size distribution of that species at the site. To achieve accurate fish species' biomass, the area $\left(100 \mathrm{~s} \mathrm{~m}^{2}\right)$ of each beach seine haul was calculated using GPS positioning (see Staveley et al. 2017 for more detailed information on fishing methods and quantification). Fish biomass was calculated (based on weight) per species and seascape for each season. In cases with subsamples, data for additional fish were calculated based on the mean of the subsample. Weight for each measured individual fish was calculated based on species-specific length-weight models from FishBase (Froese and Pauly 2018) and standardized by net area. When speciesspecific information was lacking for a species, length-weight data was calculated at the genus or family level. Each individual was assigned a life stage (i.e. adult/juvenile) and trophic level (according to FishBase), based upon measured and averaged length. Life stage was based on information for each species length at maturity from FishBase, and where information was lacking, juveniles were assigned if they were $\leq 1 / 3$ of their maximum recorded length (Nagelkerken and van der Velde 2002). Trophic levels were grouped into categories (omnivore or low-, mid- or high-level carnivore; adapted from Fishbase) to best represent the different levels found in the fish assemblage (Table 1). Response variables representing the fish assemblage were low-level, mid-level and high-level carnivore biomass, as well as total and juvenile biomass. The omnivore category was not tested as a separate model as the sole species Alburnus alburnus (Common Bleak) was only found in a few seascapes.

To test for seasonal differences between species' biomass, a Wilcoxon rank sum test was performed in R (R Development Core Team. 2018). Relationships between the habitat and seascape predictor variables upon the fish assemblage structure (biomass) in both summer and autumn were investigated using partial least squares (PLS) regressions (Wold et al. 2001) in SIMCA v. 13.0.3 (UMETRICS). Potential predictor correlations were performed and are shown in Online Resource 2.

\section{Results}

From the fish surveys, 11 species were identified from $>3000$ individuals from both seasons (Table 1; Online Resource 3). 


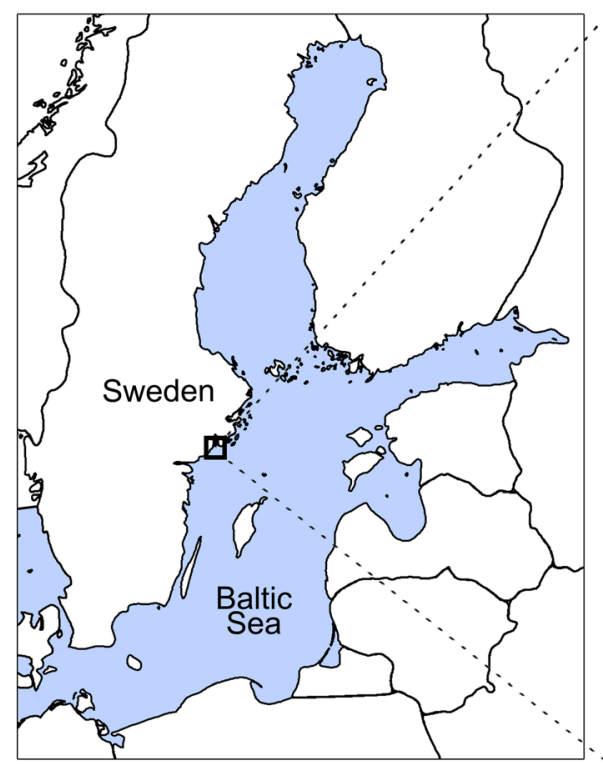

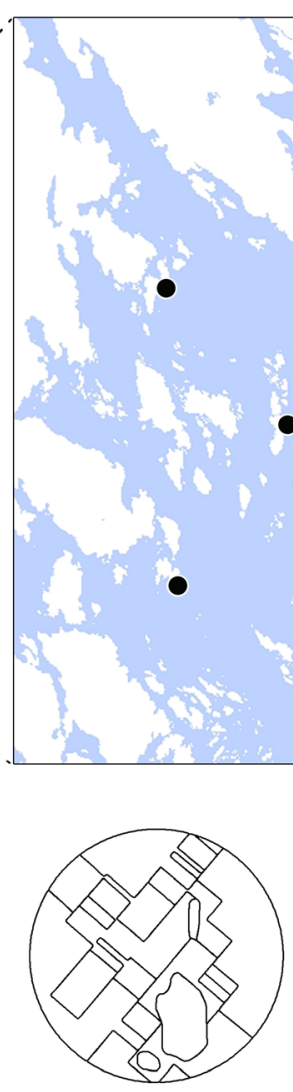

5. Total edge

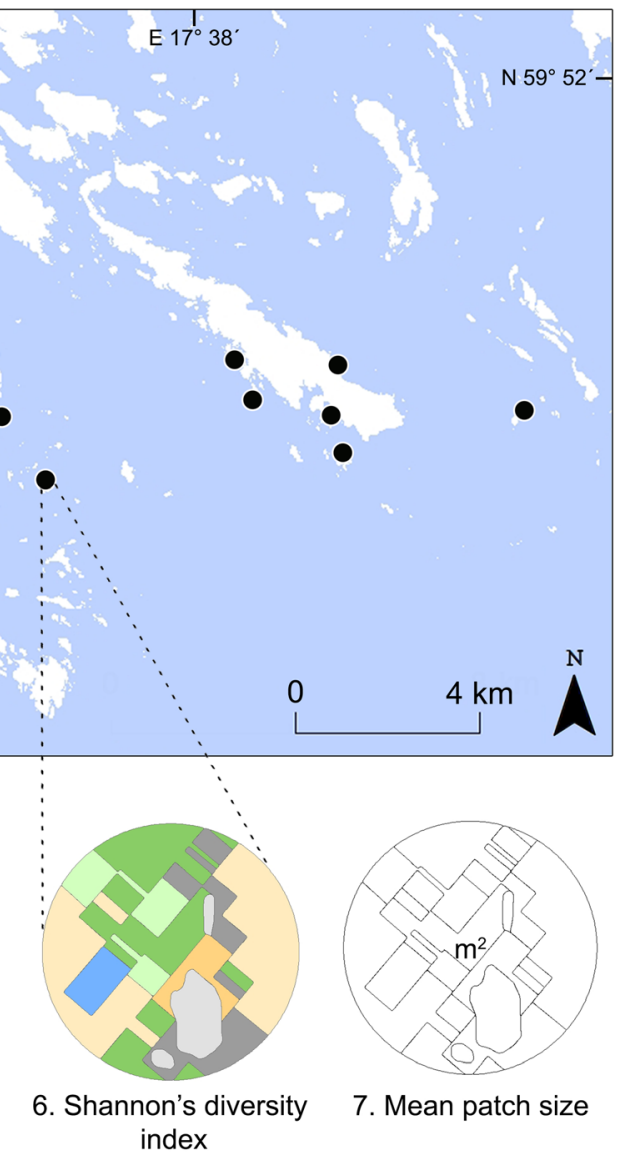

Fig. 1 Location of the study seascapes in the Baltic Sea (top) and visualization of the habitat and seascape structure predictor variables used in the study (bottom). Coastline: @Lantmäteriet

In the summer, total fish biomass $\left(\mathrm{m}^{-2}\right)$ was about six times higher compared with the autumn, whilst total fish density $\left(\mathrm{m}^{-2}\right)$ was approx. three times higher in the summer (see Online Resource 3 for detailed species densities per season). The three-spined stickleback Gasterosteus aculeatus was dominated in biomass in both seasons (Fig. 2a). Regarding trophic level structure, there was a dominance of low-level carnivores in both seasons (Fig. 2a). No significance was detected between total biomass in summer and autumn $(W=26$, $p=0.075$ ). Though, some trends in species biomass between
Table 1 List of species assigned to trophic level and category

\begin{tabular}{|c|c|c|c|}
\hline Family & Species & Trophic level & Trophic category \\
\hline Cyprinidae & Alburnus alburnus & 2.7 & Omni \\
\hline Gasterosteidae & Gasterosteus aculeatus & 3.3 & Low \\
\hline Gobiidae & Gobiusculus flavescens ${ }^{\mathrm{b}}$ & 3.2 & Low \\
\hline Syngnathidae & Nerophis ophidion $^{\mathrm{b}}$ & 4 & Mid \\
\hline Percidae & Perca fluviatilis & 4.4 & High \\
\hline Pleuronectidae & Platichthys flesus & 3.3 & Low \\
\hline Gobiidae & Pomatoschistus sp. & 3.2 & Low \\
\hline Gasterosteidae & Pungitius pungitius $^{\mathrm{a}}$ & 3.3 & Low \\
\hline Gasterosteidae & Spinachia spinachia ${ }^{\mathrm{b}}$ & 3.5 & Low \\
\hline Syngnathidae & Syngnathus typhle & 4.3 & High \\
\hline Zoarcidae & Zoarces viviparus & 3.5 & Low \\
\hline
\end{tabular}

${ }^{a}$ length-weight calculation based at genus level

${ }^{\mathrm{b}}$ length-weight calculation based at family level

Omni, omnivore; Low, low-level carnivore; Mid, mid-level carnivore; High, high-level carnivore 


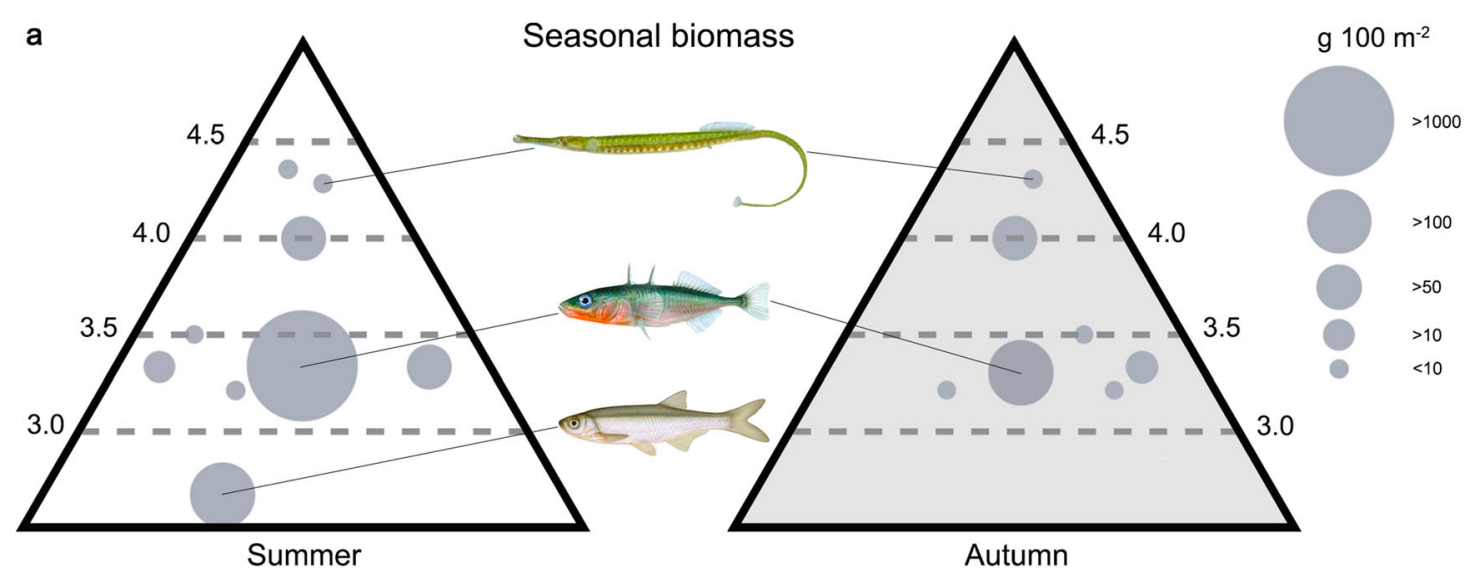

b

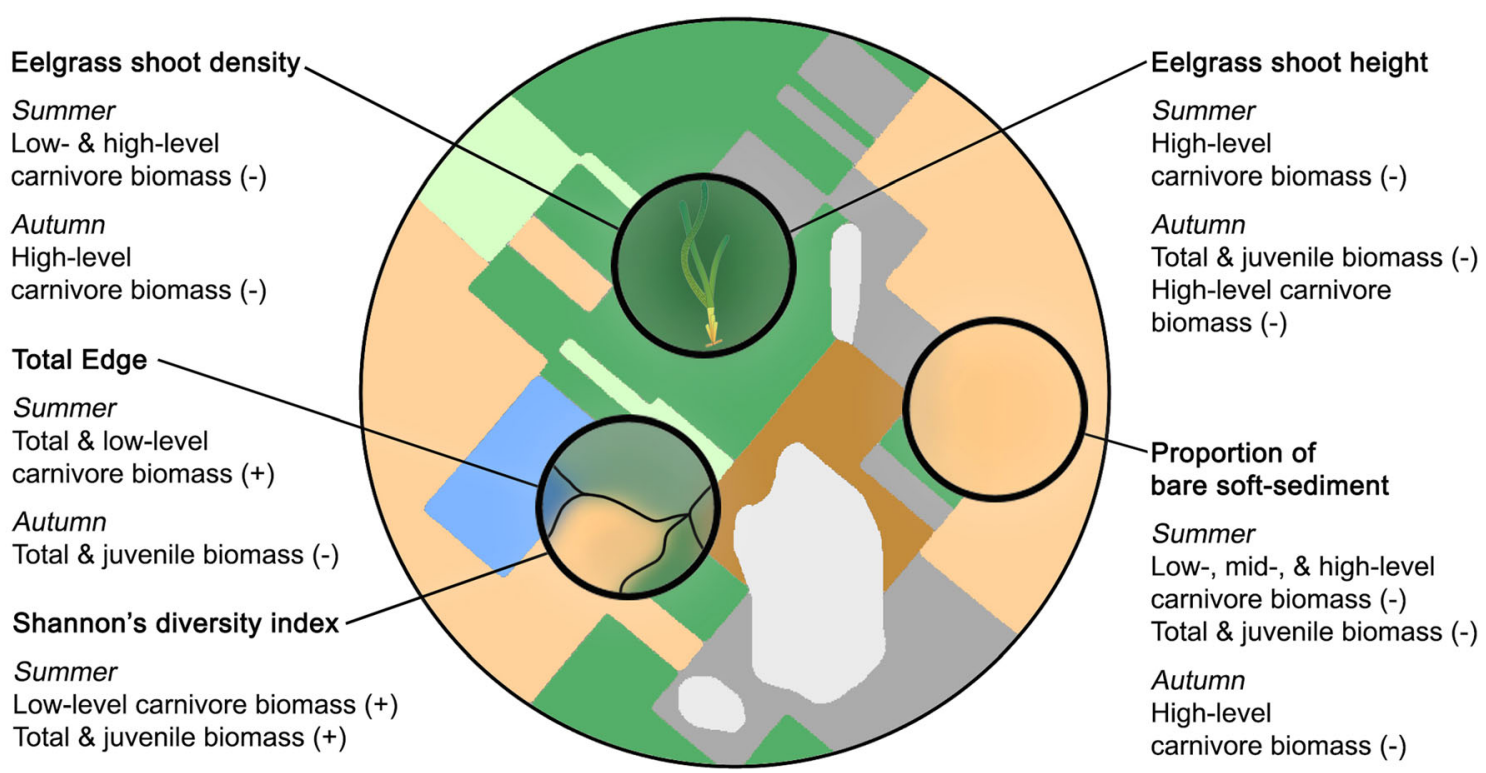

Fig. 2 a Jitter plot of the trophic level of the fish species caught in summer $(n=9)$ and autumn $(n=7)$. Circle size represents total biomass for all seascapes per season. Examples of some fish species are shown; from top to bottom: Syngnathus typhle, G. aculeatus, and A. alburnus; b Example seascape illustrating how habitat and seascape structure was related to various parts of the fish assemblage in each season. Negative

seasons can be seen for some fish species (e.g. G. aculeatus, mean values of 116 and $14 \mathrm{~kg} \mathrm{ha}^{-1}$ during summer and autumn, respectively) (Fig. 2a). The proportion of juveniles (mainly G. aculeatus specimens) was substantially higher in the autumn (46\%) compared with the summer $(2.7 \%)$.

Results from the PLS analyses showed that of the tested predictor variables, all were retained in more than one model (Table 2). The proportion of bare soft-sediment habitat was an important factor negatively affecting all parts of the tested fish assemblage variables (i.e. low-level, mid-level and high-level carnivore biomass and total and juvenile biomass), particularly in the summer (Fig. 2b; Table 2). In contrast, the Shannon's diversity index showed a positive relationship to most fish assemblage variables (i.e. low-level carnivore biomass and total and positive relationships are indicated by $(-)$ and $(+)$, respectively. The light grey area defines land; dark grey, rock; blue, blue mussel bank; brown, rock with mixed vegetation; orange, bare soft sediment; light green, soft sediment with mixed vegetation and dark green, Zostera marina. Fish drawings are published with permission from the Swedish Species Information Centre (ArtDatabanken), SLU

and juvenile biomass) in the summer (Fig. 2b; Table 2). Total edge showed a positive relationship to some variables (i.e. total biomass and low-level carnivore biomass) in the summer, but a negative relationship to other variables (i.e. total and juvenile biomass) in the autumn. With regard to the smaller-scale habitat structure (i.e. shoot height and density), both of these variables revealed negative relationships with high-level carnivores in both seasons, while only shoot height had negative relationships with total and juvenile biomass in the autumn (Fig. 2b; Table 2). All PLS models showed good predictability (crossvalidated variance $>0.05$ ), and the cumulative fraction of all predictor variables combined explained between 41 and $87 \%$ (depending on response variable) of the variation, which indicated a very good fit of the models (Table 2). 
Table 2 Data summary of PLS models for summer and autumn

\begin{tabular}{|c|c|c|c|c|}
\hline & Response variable & Coefficient & $R_{\mathrm{y}}{ }^{2}$ cum & $Q^{2}$ \\
\hline \multicolumn{5}{|l|}{ Summer } \\
\hline \multirow[t]{3}{*}{ Total biomass } & Bare soft sediment & -0.186 & 0.407 & 0.216 \\
\hline & Shannon's & 0.206 & & \\
\hline & Total edge & 0.196 & & \\
\hline \multirow[t]{2}{*}{ Juvenile biomass } & Bare soft sediment & -0.235 & 0.624 & 0.262 \\
\hline & Shannon's & 0.271 & & \\
\hline \multirow[t]{4}{*}{ Low-level carnivore biomass } & Bare soft sediment & -0.195 & 0.410 & 0.243 \\
\hline & Shannon's & 0.202 & & \\
\hline & Total edge & 0.166 & & \\
\hline & Shoot density & -0.146 & & \\
\hline \multirow[t]{2}{*}{ Mid-level carnivore biomass } & Bare soft-sediment & -0.229 & 0.946 & 0.697 \\
\hline & Zostera & 0.650 & & \\
\hline \multirow[t]{3}{*}{ High-level carnivore biomass } & Bare soft sediment & -0.302 & 0.683 & 0.454 \\
\hline & Shoot density & -0.314 & & \\
\hline & Shoot height & -0.214 & & \\
\hline \multicolumn{5}{|l|}{ Autumn } \\
\hline \multirow[t]{3}{*}{ Total biomass } & Total edge & -0.332 & 0.668 & 0.393 \\
\hline & Shoot height & -0.323 & & \\
\hline & Patch size & 0.240 & & \\
\hline \multirow[t]{2}{*}{ Juvenile biomass } & Total edge & -0.418 & 0.512 & 0.064 \\
\hline & Shoot height & -0.370 & & \\
\hline \multirow[t]{3}{*}{ High-level carnivore biomass } & Bare soft sediment & -0.324 & 0.821 & 0.727 \\
\hline & Shoot density & -0.319 & & \\
\hline & Shoot height & -0.344 & & \\
\hline
\end{tabular}

$R_{\mathrm{y}}{ }^{2}$ cum is the cumulative fraction of all predictor variables (i.e. explained variation) and $Q^{2}$ is the cross-validated variance which needs to be $>0.05$ to be significant. Note: low- and mid-level carnivore biomass models for the autumn were not generated

\section{Discussion}

In this study, seagrass habitat structure, habitat patch diversity, total edge and bare soft-sediment habitat had a significant influence on seagrass fish assemblage biomass. Within the fish assemblage, the meso-predator G. aculeatus was clearly dominated, while larger predatory fish were seldom found.

From the PLS analyses, the area of Z. marina habitat in the seascape as well as mean patch size did not generally show a significant relationship with the different fish variables. Nonetheless, the negative relationships with seagrass shoot height and density, together with the positive influence of patch heterogeneity (Shannon's diversity index), suggest that the Z. marina habitat itself in the Baltic Sea may not have the same functional role with regard to the fish assemblage as in others parts of the world (e.g. Jackson et al. 2006; Staveley et al. 2017; Scapin et al. 2018). For example, in the study by Staveley et al. (2017), seagrass was often the dominant structurally complex vegetation type in the shallow water sites; therefore, perhaps implying that the reliance on the abundance of the $Z$. marina habitat on the Swedish west coast is higher for the fish community compared with meadows in the Baltic Sea, where a which can suit the needs for mobile fish species. Likewise, some species found in this study may not express a high degree of specific habitat or patch attachment (such as presented here by the positive relationship to Shannon's diversity index) as what might be observed for other fish species in Z. marina meadows elsewhere. For example, G. aculeatus migrates from the more open pelagic parts of the Baltic Sea to the coastal environments in spring and summer to spawn (Bergström et al. 2015), which was seen by the 10-fold higher biomass in the summer compared with the autumn. In particular, as the amount of bare soft sediment had a negative influence on fish, this suggests that a higher biomass of fish would be found in seagrass meadows with less unvegetated and more structurally complex habitats in the surrounding seascape. This further postulates that $G$. aculeatus is not linked to any specific species of submerged aquatic vegetation as such, but rather to the structure of the shallow coastal system (Perry et al. 2018a; Gagnon et al. 2019), particularly at certain times of year (i.e. early summer for spawning).

This study showed that $G$. aculeatus had by far the highest biomass of all fish species found in $Z$. marina habitat in both summer and autumn. The density of G. aculeatus has increased strongly multitude of other vegetation types is within close proximity 
in Baltic Sea coastal areas; a recent study reported a 45-times increase from 1980 to 2011 in the central Baltic Sea (Bergström et al. 2015). In Z. marina meadows on the Swedish west coast, this species has also increased substantially in the past few decades and is now one of the most abundant fish found in these habitats (Baden et al. 2012; Staveley et al. 2017; Perry et al. 2018b).

The large increase of $G$. aculeatus and other meso-predators in coastal areas has been suggested to be linked to the drastic decline in larger predatory fish, such as Gadus morhua and Salmo trutta (Eriksson et al. 2011; Baden et al. 2012; Bergström et al. 2015). We also found very few top predators in the seagrass meadows in our study, which may in part reflect the poor situation for several large predatory fish species in the Baltic Sea. The main large piscivore in the open Baltic, Gadus morhua, has declined dramatically (e.g. Österblom et al. 2007) and has become a rare coastal visitor in the northern Baltic Sea. Coastal piscivores such as Perca fluviatils and Esox lucius have also declined in some areas, including in the northern Baltic Sea (Ljunggren et al. 2010; Östman et al. 2016). However, it is also possible that larger predatory fish rely more on other vegetation habitats, for instance reeds (Phragmites australis; Kallasvuo et al. 2011) and meadows of freshwater angiosperms in sheltered bays, than on Z. marina habitats in this region of the Baltic Sea. Further investigation in seagrass meadows would be necessary throughout this region specifically during twilight and night hours to gain a more comprehensive assessment of the fish assemblage, particularly as predatory fish are known to visit seagrass meadows during these times to predate (Shoji et al. 2017).

For $G$. aculeatus, shallow coastal areas act as nursery habitat (for instance, as described in Bergström et al. 2015). We show that $Z$. marina meadows seem to be included in the nursery habitat of this species as nearly half of the fish assemblage comprised of juvenile fish in the autumn (resulting from earlier spawning of $G$. aculeatus). In contrast, the coastal fish species P. fluviatilis and Rutilus rutilus do not seem to use this as nursery habitat, which is in line with what has been shown previously for these species, as they mainly spawn in sheltered bays that warm up early in the spring (e.g. Snickars et al. 2010; Sundblad et al. 2011). To further investigate the nursery hypothesis, at a meadow (Heck 2003) or larger interconnecting seascape (Nagelkerken et al. 2015) scale, other habitats (e.g. bare soft sediment, freshwater vegetation) and their associated fish community would need to be assessed (e.g. Perry et al. 2018a) as well as further investigation into ecological connectivity in the Baltic Sea.

Here, we focused on a landscape patch mosaic perspective and did not explicitly investigate the effects of environmental conditions (e.g. water transparency, wave exposure, salinity). However, we acknowledge that this could play a part in determining spatial and temporal variations in fish distributions and habitat usage in the Baltic Sea, as other studies have indicated (Sundblad et al. 2014; Snickars et al. 2014). Nonetheless, in this study, exposure, salinity and Secchi depth likely vary little between the investigated sites.

Results from this study give new information on habitat spatial patterning associating to fish biomass in the Baltic Sea. In the
Z. marina habitats, high biomass of $G$. aculeatus concurs with findings from other coastal habitats. The findings also show the importance of considering both small- and large-scale variables (from $10 \mathrm{~s} \mathrm{~m}$ to $\mathrm{km}$ ) when assessing drivers of fish in shallow water environments. Further knowledge is still needed on the functional and ecological role of these important yet vulnerable seagrass habitats, which can be transposed into management plans and conservation strategies to aid marine stewardship in the Baltic Sea.

Acknowledgements Thanks go to the staff at Askö Laboratory, Stockholm University, for help with equipment and boats, and to Viktor Birgersson for assistance in the field.

Funding information Open access funding provided by Stockholm University. This study was funded by The Swedish Research Council Formas (grant number 2011-1640). SAW was supported by the Baltic Eye project. A scholarship from Albert \& Maria Bergströms stiftelse was also gratefully received (NS).

\section{Compliance with ethical standards}

Conflict of interest The authors declare that they have no conflict of interest.

Ethical approval All applicable international, national, and/or institutional guidelines for the care and use of animals were followed. Ethical permission was granted from The Swedish Board of Agriculture (number: 131-2014).

Sampling and field studies Permits for sampling and observational field studies are not applicable.

Data availability The datasets generated during and/or analysed during the current study are available from the corresponding author on reasonable request.

Author contribution TABS, PH, NS, SAW and MG conceived and designed research. TABS, PH, NS and FVDM conducted field work. TABS, $\mathrm{PH}$ and MG analyzed data. All authors contributed to writing the manuscript. All authors read and approved the manuscript.

Open Access This article is licensed under a Creative Commons Attribution 4.0 International License, which permits use, sharing, adaptation, distribution and reproduction in any medium or format, as long as you give appropriate credit to the original author(s) and the source, provide a link to the Creative Commons licence, and indicate if changes were made. The images or other third party material in this article are included in the article's Creative Commons licence, unless indicated otherwise in a credit line to the material. If material is not included in the article's Creative Commons licence and your intended use is not permitted by statutory regulation or exceeds the permitted use, you will need to obtain permission directly from the copyright holder. To view a copy of this licence, visit http://creativecommons.org/licenses/by/4.0/.

\section{References}

Baden S, Emanuelsson A, Pihl L et al (2012) Shift in seagrass food web structure over decades is linked to overfishing. Mar Ecol Prog Ser 451:61-73. https://doi.org/10.3354/meps09585 
Baden SP, Boström C (2001) The leaf canopy of seagrass beds : faunal community structure and function in a salinity. In: Reise K (ed) Ecological comparisons of sedimentary shores. Springer-Verlag, Berlin Heidelberg, pp 213-236

Bergström U, Olsson J, Casini M et al (2015) Stickleback increase in the Baltic Sea-a thorny issue for coastal predatory fish. Estuar Coast Shelf Sci 163:134-142. https://doi.org/10.1016/j.ecss.2015.06.017

Boström C, Baden S, Bockelmann A-C et al (2014) Distribution, structure and function of Nordic eelgrass (Zostera marina) ecosystems: implications for coastal management and conservation. Aquat Conserv Mar Freshw Ecosyst. https://doi.org/10.1002/aqc.2424

Boström C, Jackson E, Simenstad C (2006) Seagrass landscapes and their effects on associated fauna: a review. Estuar Coast Shelf Sci 68:383403. https://doi.org/10.1016/j.ecss.2006.01.026

Costa B, Walker BK, Dijkstra JA (2018) Mapping and quantifying seascape patterns. In: Pittman SJ (ed) Seascape Ecology. Wiley Blackwell, Oxford, UK, pp 27-56

Eriksson BK, Sieben K, Eklöf J et al (2011) Effects of altered offshore food webs on coastal ecosystems emphasize the need for crossecosystem management. Ambio 40:786-797. https://doi.org/10. 1007/s13280-011-0158-0

Froese R, Pauly D (2018) FishBase. www.fishbase.org, version (10/ 2018).

Gagnon K, Gräfnings M, Boström C (2019) Trophic role of the mesopredatory three-spined stickleback in habitats of varying complexity. J Exp Mar Bio Ecol 510:46-53. https://doi.org/10.1016/j. jembe.2018.10.003

Gillanders BM, Able KW, Brown JA et al (2003) Evidence of connectivity between juvenile and adult habitats for mobile marine fauna: an important component of nurseries. Mar Ecol Prog Ser 247:281-295. https://doi.org/10.3354/meps247281

Gullström M, Bodin M, Nilsson P, Öhman M (2008) Seagrass structural complexity and landscape configuration as determinants of tropical fish assemblage composition. Mar Ecol Prog Ser 363:241-255. https://doi.org/10.3354/meps07427

Heck KL, Carruthers TJB, Duarte CM et al (2008) Trophic transfers from seagrass meadows subsidize diverse marine and terrestrial consumers. Ecosystems 11:1198-1210. https://doi.org/10.1007/ s10021-008-9155-y

Heck KLJ (2003) Critical evaluation of nursery hypothesis for seagrasses. Mar Ecol Prog Ser 253:123-136. https://doi.org/10.3354/ meps 253123

Jackson EL, Attrill MJ, Jones MB (2006) Habitat characteristics and spatial arrangement affecting the diversity of fish and decapod assemblages of seagrass (Zostera marina) beds around the coast of Jersey (English Channel). Estuar Coast Shelf Sci 68:421-432. https://doi.org/10.1016/j.ecss.2006.01.024

Jackson EL, Rowden AA, Attrill MJ et al (2001) The importance of seagrass beds as a habitat for fishery species. In: Gibson R, Barnes M, Atkinson R (eds) Oceanography and marine biology, an annual review, 1st edn. Taylor \& Francis, London, UK, pp 269-303

Kallasvuo M, Lappalainen A, Urho L (2011) Coastal reed belts as fish reproduction habitats. Boreal Environ Res 16:1-14

Kullander SO, Nyman L, Jilg K, Delling B (2012) Nationalnyckeln till Sveriges flora och fauna. Ryggsträngsdjur: Strålfeniga fiskar. Chordata: Actinopterygii. ArtDatabanken, SLU, Uppsala

Ljunggren L, Sandström A, Bergström U et al (2010) Recruitment failure of coastal predatory fish in the Baltic Sea coincident with an offshore ecosystem regime shift. ICES J Mar Sci 67:1587-1595. https://doi. org/10.1093/icesjms/fsq109

Nagelkerken I, Sheaves M, Baker R, Connolly RM (2015) The seascape nursery: a novel spatial approach to identify and manage nurseries for coastal marine fauna. Fish Fish 16:362-371. https://doi.org/10. 1111/faf.12057

Nagelkerken I, van der Velde G (2002) Do non-estuarine mangroves harbour higher densities of juvenile fish than adjacent shallow- water and coral reef habitats in Curacao (Netherlands Antilles)? Mar Ecol Prog Ser 245:191-204

Österblom H, Hansson S, Larsson U et al (2007) Human-induced trophic cascades and ecological regime shifts in the Baltic Sea. Ecosystems 10:877-889. https://doi.org/10.1007/s10021-007-9069-0

Östman Ö, Beier U, Bergek S, Hentati-Sundberg J (2016) Beståndsstatus hos abborre, gädda, sik och gös i de stora sjöarna och längs kusten Innehållsförteckning. SLU Aqua, Öregrund, Sweden

Perry D, Staveley TAB, Gullström M (2018a) Habitat connectivity of fish in temperate shallow-water seascapes. Front Mar Sci 4. https://doi. org/10.3389/fmars.2017.00440

Perry D, Staveley TAB, Hammar L et al (2018b) Temperate fish community variation over seasons in relation to large-scale geographic seascape variables. Can J Fish Aquat Sci 75:1723-1732. https://doi.org/ 10.1139/cjfas-2017-0032

Pittman SJ, Kneib RT, Simenstad CA (2011) Practicing coastal seascape ecology. Mar Ecol Prog Ser 427:187-190. https://doi.org/10.3354/ meps09139

Pittman SJ, McAlpine CA, Pittman KM (2004) Linking fish and prawns to their environment: a hierarchical landscape approach. Mar Ecol Prog Ser 283:233-254. https://doi.org/10.3354/meps283233

Development Core Team R (2018) R: a language and environment for statistical computing. R A Lang. Environ. Stat, Comput

Scapin L, Zucchetta M, Sfriso A, Franzoi P (2018) Local habitat and seascape structure influence seagrass fish assemblages in the Venice Lagoon: the importance of conservation at multiple spatial scales. Estuar Coasts:1-16. https://doi.org/10.1007/s12237-0180434-3

Shoji J, Mitamura H, Ichikawa K et al (2017) Increase in predation risk and trophic level induced by nocturnal visits of piscivorous fishes in a temperate seagrass bed. Sci Rep 7:1-10. https://doi.org/10.1038/ s41598-017-04217-3

Snickars M, Gullström M, Sundblad G et al (2014) Species-environment relationships and potential for distribution modelling in coastal waters. J Sea Res 85:116-125. https://doi.org/10.1016/j.seares.2013. 04.008

Snickars M, Sundblad G, Sandström A et al (2010) Habitat selectivity of substrate-spawning fish: modelling requirements for the Eurasian perch Perca fluviatilis. Mar Ecol Prog Ser 398:235-243. https:// doi.org/10.3354/meps08313

Staveley TAB, Perry D, Lindborg R, Gullström M (2017) Seascape structure and complexity influence temperate seagrass fish assemblage composition. Ecography (Cop) 40:936-946. https://doi.org/10. 1111/ecog.02745

Sundblad G, Bergström U, Sandström A (2011) Ecological coherence of marine protected area networks: a spatial assessment using species distribution models. J Appl Ecol 48:112-120. https://doi.org/10. 1111/j.1365-2664.2010.01892.x

Sundblad G, Bergström U, Sandström A, Eklöv P (2014) Nursery habitat availability limits adult stock sizes of predatory coastal fish. ICES J Mar Sci 71:672-680. https://doi.org/10.1093/icesjms/fst056

Valentine JF, Heck KL, Blackmon D et al (2007) Food web interactions along seagrass-coral reef boundaries: effects of piscivore reductions on cross-habitat energy exchange. Mar Ecol Prog Ser 333:37-50. https://doi.org/10.3354/meps333037

Waycott M, Duarte CM, Carruthers TJB et al (2009) Accelerating loss of seagrasses across the globe threatens coastal ecosystems. Proc Natl Acad Sci U S A 106:12377-12381. https://doi.org/10.1073/pnas. 0905620106

Wold S, Sjöström M, Eriksson L (2001) PLS-regression: a basic tool of chemometrics. Chemom Intell Lab Syst 58:109-130

Publisher's note Springer Nature remains neutral with regard to jurisdictional claims in published maps and institutional affiliations. 